OPEN ACCESS

Vol. 8, No. 1, April, 2020

Page. $36-43$

DOI: https://doi.org/10.21107/jaffa.v8i1.7010
JOURNAL OF AUDITING, FINANCE, AND FORENSIC ACCOUNTING

E-ISSN: 2461-0607 ISSN: 2339-2886

https://journal.trunojoyo.ac.id/jaffa/

\title{
Internal Control Effectiveness of Financial Management In Private Higher Education
}

\author{
Ernawati $^{1}$; Imam Agus Faiso12
}

${ }^{1}$ Accounting Study Program, Islamic University of Madura, Indonesia

${ }^{2}$ Accounting Study Program, University of Trunojoyo Madura, Indonesia

\section{Article Info:}

Received: 28 February 2020 in revised form: 21 March 2020

Accepted: 31 March 2020

Available Online: 13 April 2020

\section{Keywords:}

Internal Control, Financial Management, Effectiveness, And Kelabu College

\section{Corresponding Author:}

Email: imam.faisol@trunojoyo.ac.id

\begin{abstract}
This research investigates internal control effectiveness in supporting financial management of higher education institutions. The object of this research is an Internal Supervisory Unit at a private higher education named "Kelabu College" on island X. This research uses qualitative method with interview, observation, and documentation techniques. The research results show that the role of internal supervisory unit in investigating and controlling financial of higher education institutions has not been fully implemented. The research results also show that the aspect of internal control such as monitoring activities and risk assessment has not been carried out properly. While, aspects of information and communication, control activities, and control environment have been well implemented.
\end{abstract}

Abstrak; Penelitian ini meneliti peran efektivitas pengendalian internal dalam mendukung manajemen keuangan pada institusi pendidikan tinggi. Objek penelitian ini adalah Unit Pengawas Internal pada sebuah pendidikan tinggi swasta yaitu "Perguruan Tinggi Kelabu" pada pulau X. Penelitian ini menggunakan metode kualitatif dengan teknik wawancara, observasi, dan dokumentasi. Hasil penelitian menunjukkan bahwa peran unit pengawas internal dalam memeriksa dan mengendalikan keuangan pada institusi pendidikan tinggi tidak sepenuhnya diimplementasikan. Hasil penelitian juga menunjukkan bahwa aspek pengendalian internal seperti aktivitas pengawasan dan penilaian risiko tidak dilaksanakan sebagaimana mestinya. Sedangkan, aspek informasi dan komunikasi, aktivitas pengendalian, dan lingkungan pengendalian sudah diterapkan dengan baik. 


\section{INTRODUCTION}

Private higher education institutions as a part of the ministry of education and culture must carry out the mandate contained in the Regulation of the Minister of National Education number 16 of 2009 to form an Internal Supervisory Unit (SPI) (Depdiknas, 2009). Internal Supervisory Unit (SPI) is an organization in a university that carries out supervisory functions in non-academic field for and on behalf of the rector. The scope of non-academic control includes: finance, facilities and infrastructure as well as human resources. Private higher education institutions according to Law No. $12 / 2012$ are higher education institutions established and/or organized by the community by establishing a legal entity organizer with non-profit principle (Kemendikbud, 2012). To prepare a financial statement, private higher education uses statements of financial accounting standards (PSAK) 45 for non-profit organizations. In addition, for the aspect of recognition, higher education institutions can use PSAK for entities without public accountability (SAK ETAP) which includes a balance sheet, income statement, cash flow, and notes of financial statements. Private higher education institutions commonly use accounting cycle as in the government sector. Private higher education institutions start their activities from the process of planning (budgeting), budget realization, recording/administration, reporting, accountability, and evaluation. The stages of preparing the financial statements of private higher education are generally classified into four stages starting from the planning, recording, grouping, and reporting.

In realizing good financial management, every private higher education institution in Indonesia requires an Internal Supervisory Unit (SPI) to investigate and control finances at institution so that the entity's vision and mission can be realized and implemented well. A private higher education institution is laden to financial planning (budget) process that is used in all aspects from development to financing. The funds are for operations, development, vision and mission of the private higher education. To realize the vision and mission of private higher education, transparency and accountability in using funds are required for all activities. Thus, higher education institution academicians and the public in general can monitor and provide suggestions to the higher education activities. Therefore, transparency and accountability especially in financial statements are very important for various parties.

Higher education as a non-governmental organization (NGO) needs to improve the control especially in finance. Poor financial control in higher education cause many cases that are potential for fraud. For example, corruption case in the procurement and installation of information technology at University of Indonesia's central library building in the fiscal year 2010-2011 and the management of public funds in 20092011 which raised the potential for state financial losses (Detik, 2014). In addition, the audit results on Kelabu College's financial statements in 2017 and 2018 conducted by the Public Accountant Office had an unqualified opinion. However, if compared with the results of internal control evaluation conducted by the internal supervisory unit, there were a number of activities that did not comply with the spirit of GCG. Differences of opinion between external and internal auditors are the symptoms of inappropriate control and management activities. The discrepancy lies in financial activities, especially in the planning and administration of financial statements.

Research on the effectiveness of internal control has been carried out by several researchers. Asy'ari et al (2013); Pontoh (2013); Puspitarini (2012); Trials (2017) investigate the role of internal supervisory unit in higher education institutions. This research aims to evaluate and analyze the effectiveness of internal supervisory unit in investigating and controlling financial management of higher education institutions. The researcher performed evaluation and analysis by referring to the COSO framework which states that internal control is designed to provide adequate confidence in the objectives of the entity (COSO, 2013). The results of this research, especially for Kelabu College, are expected to be used as a basis to evaluate internal control system and support decision making. 


\section{LITERATURE REVIEW AND HYPOTHESES DEVELOPMENT}

\section{coso (Committee of Sponsoring Organizations of the Treadway)}

COSO is an internal control system that entire process is performed by all employees both top managers, middle managers and low managers. The design aims to provide adequate confidence in achieving targets and objectives of the entity. There are four points that become priorities for achieving the objectives of the entity, that are the reliability of financial statements, compliance with the applicable laws and regulations, and the effectiveness and efficiency of the entity. COSO consists of 5 elements including control environment, risk assessment, control activities, communication and information and monitoring activities (COSO, 2013).

Control environment is the foundation and reference for other COSO elements. The control environment forms ideal conditions for organization both at personal and entity level. The ideal control environment will show a good situation and contribute good effect to the entity. Aisyah \& Asmawanti (2017) stated that in order to understand and assess the control environment, auditors must consider the most important control elements including ethical values and integrity, commitment to improve competency, management style and philosophy, and human resource policies and practices. Risk assessment is an activity of identifying the emergence of risk so that it can be mitigated. For assessing the risk in preparation of entity's financial statements, it includes the suitability of information and financial presentation with the financial accounting standards (SAK).

Control activity is defined as the activity through SOP documents and entity regulations for top management to achieve the vision and mission of the entity by ensuring that measure has been taken to reduce risk. Control activity is a series of structured and systematic activities. Kumaat (2011) stated that the series of these activities include approval, authorization, verification, reconciliation, performance review, securing of assets and segregation of functions. The last COSO component is information and communication as an important element in internal control activities. Information is needed by the directors of the entity as a guideline for internal control activities.

\section{Internal and Financial Controls}

Internal control is evaluation of all activities and testing the suitability of information with the standards/provisions set by the entity. The auditor can use confirmation audit techniques/procedures and tracing to ensure the suitability of the information. The ultimate goal of internal control is to ensure that the operational activities of the entity are running effectively and efficiently. Halim (2015) stated that the objectives of internal control including reporting the audit results and monitoring, providing suggestions and feedback objectively and independently of the audit findings.

Financial control activities are identical to internal control, but the focus of the audit is on financial activities. Financial activities can be defined from the initial cycle (planning) to the preparation of financial statements. Ulum (2012) stated that financial control can be performed regularly and continuously to avoid material misstatements and errors. The rules used in the practice of financial control are the suitability of financial information with the guidelines or Financial Accounting Standards (SAK). In addition to the suitability of information, other activities are realization and financial accountability to the entity. The essence of financial control is as a preventive measure against fraud that is harmful to the entity.

\section{Financial Statements of Non-Profit Organization}

The financial statements of non-profit organizations provide information regarding financial position and activities of the entity. This information can be useful for users of financial statements. Financial statements users of private higher education include private higher education foundation, students, and private higher education academicians. Students, as one of the most important users, are supporting part of the main resources for the sustainability of private higher education. Delivery of financial information by the entity's report organizer can refer to PSAK 45. Commonly, the nonprofit organization's financial statements are the same as company, but there are several different terms including the statement of financial position (accounting profit 
refers to the balance sheet) and the activity report (income statement in commercial accounting).

The financial statements of non-profit organizations that contrast to commercial accounting are the presentation of equity positions and the difference between income and expenses (Hasana, 2011). The equity position of non-profit organization is called as net assets. Net assets according to PSAK 45 consist of unrestricted net assets, permanent restricted net assets, and temporary restricted net assets. For unrestricted net assets, the use is not restricted and is for the entity's purpose while restricted net assets are bound to be restricted both permanently and temporarily.

\section{Conceptual Framework}

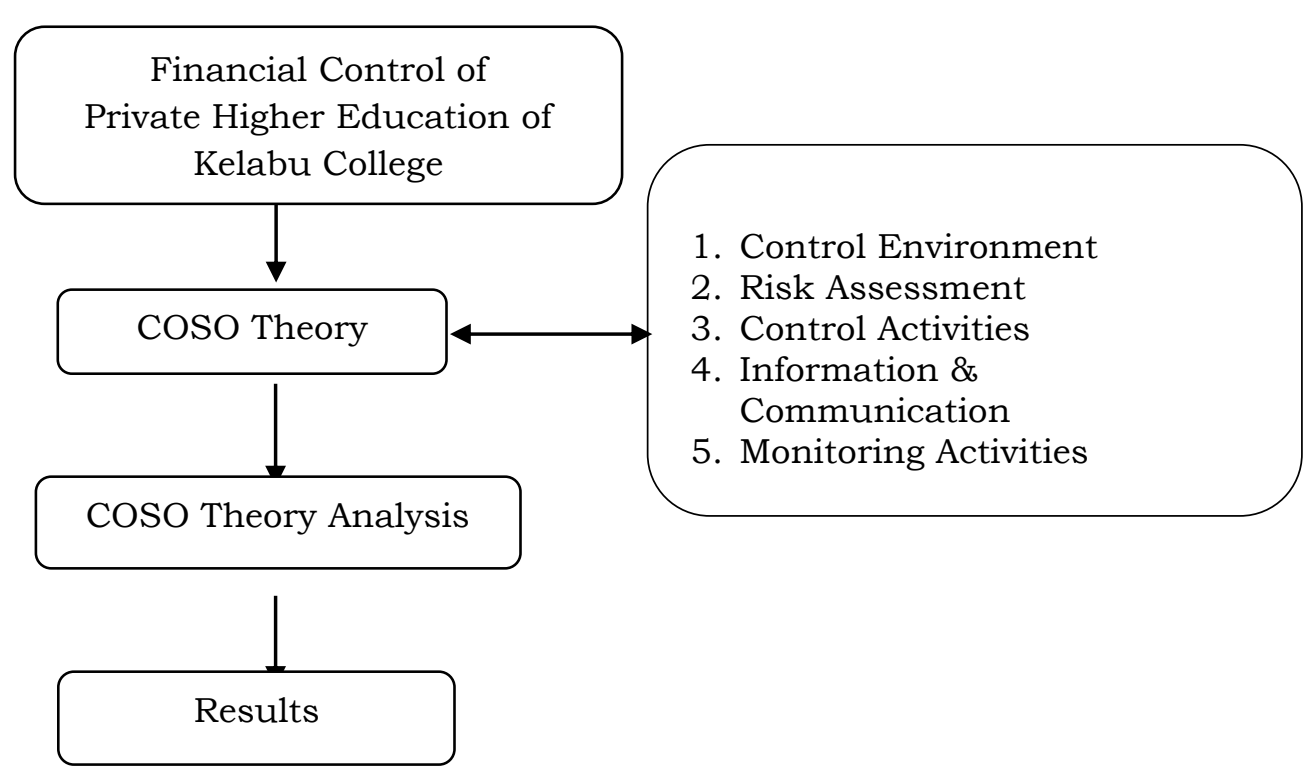

Figur 1. Conceptual Framework

The effectiveness of internal supervisory unit at a private higher education on island $\mathrm{X}$ was analyzed and evaluated using the COSO Theory. COSO theory consists of 5 elements including Control Environment, Risk Assessment, Control Activities, Information \& Communication, and Monitoring Activities. This research used a qualitative method with interview, observation, and documentation techniques. The research results explain and conclude about the role of internal supervisory unit in investigating and controlling financial management of higher education institutions.

\section{RESEARCH METHODOLOGY}

This research uses qualitative approach to investigate and explain phenomena in question. Qualitative approach is used in order to make data collection can grow and fit with the field conditions. This research paradigm is interpretive that focusing on one's interpretation of conditions/cases. According to Moleong (2007), interpretive paradigm is an attempt to obtain deeper and broader meanings of the research results. This research is conducted in a private higher education on Island X. Kelabu College is selected as the research location because of the availability of access to information and proximity to informants.

This research object is Internal Supervisory Unit of Kelabu College. The informants of this research were those who meet the criteria to be the part of the control institution and were directly involved in the supervision process. They included the head and secretary of SPI, and Rector of Kelabu College. The head and secretary of SPI had the role of controlling the finance of Kelabu College meanwhile The Rector of Kelabu College is in charge of achieving the campus vision and mission, realizing work programs, and administering financial in the institution.

This research uses two types of data, primary and secondary data. The primary data in this research are data obtained directly from the observation and interview with 
the head of internal supervisory unit of Kelabu College and the head of financial sector. The secondary data in this research is in the form of documentation including organizational structure, SOP (Standard operating procedures), independent auditor's statements, and the SPI examination results. Data analysis in this research included data reduction, namely the process of selecting, focusing, paying attention, simplifying, abstracting, and transforming data from the interview and observation. Reduced data provided a clear description and made it easier for the researcher to perform further data collection. The data presentation of this research is describing the research results during observation and interview using COSO theory consisting of 5 elements including control environment, risk assessment, control activities, information $\&$ communication, and monitoring activities.

\section{FINDINGS AND DISCUSSION}

Financial control aims to ensure that the prepared budget is realized properly in accordance with the set budget. To ensure that the control runs well, a good internal control system and internal supervisory unit are needed to monitor the activities. The first COSO instrument is the control environment with several elements including tenforcement of integrity and ethical values, commitment to improve competency, conducive direction, establishing organizational structure that suits the needs, delegation of authority and appropriate responsibility, preparation and application of HR development policies, realizing the role of effective SPI and good working relations with Kelabu College. Atus stated that:

"The code of ethics for lecturers and employees already exists ... the organizational structure has become a reflection of the authority and responsibilities delegation ... for human resource development, we have done $i t^{\prime \prime}$

In line with Atus, Asep said:

"We (SPI) have synergized with the directors ... all (code of ethics and organizational structure) is available"

Control environment at the Kelabu college is formed and runs optimally both on the element of appropriate authority and responsibilities delegation, the formulation and implementation of HR development policies, the effective role of SPI realization, and good working relations. SPI at the Kelabu College is responsible to ensure that nonacademic management (finance and HR) has been performed in accordance with the procedures. The five elements of control based on COSO theory should be a reference and basis for developing internal control. The second COSO instrument, risk assessment, is an activity to identifies and analyzes risk. So, it can be estimated the intensity and subsequent actions to minimize these risks. SPI at the Kelabu College had not conducted a risk assessment, as stated by Asep:

"The risk on this college has not been assessed yet ... actually, it has been considered ... but it has not been set forth in an appropriate risk assessment, such as markup risk of fixed asset prices, uncontrolled spending"

Funds manipulation and fraud of asset procurement is one of the cases that sometimes occurs in private higher education institutions. SPI at the Kelabu College needs to plan risks that arise and are potential to be a threat to the higher education performances. In fact, SPI has designed potential risks but they need to be further identified and set forth in the form of risk assessment documents. This instrument simplifies the internal auditors to conduct control especially in finance.

The third instrument is control activities. The aim of control is to reduce risk of financial management. There are several elements of control activities, namely developing human resources, controlling of managing information systems, controlling of physical assets, determining performance indicators, segregration of functions, and accurate and on time recording. Regarding control activities, Asep explained: 
"HR already has plans for both employees and lecturers, we have them joined the training, character seminar, workshop, and others. Of course, this participation can improve the skills of lecturers"

The explanation emphasize that Kelabu College prepared a human resource development plan. However, the focus of human resource development lies in the ability to teach and the three pillars of higher education. The development of financial HR skills has not been fully implemented. Therefore, the next concrete step is that Kelabu college needs to set the system development, especially financial information system. Of course, the development of financial system can increase the transparency of planning and use of funds. Asep said:

"..... yes, the financial information system is important, although it is expensive but it will be useful for the future, the campus needs to plan and design a financial system. The combination of good financial human resources and adequate system can facilitate the university financial control ..."

Competent financial human resources and a good financial information system can result in a good asset procurement. So far, the problem in procurement and recording assets at Kelabu College remains a crucial problem. The procurement stage has no clear guidelines. In fact, the expenditure of goods is not well recorded. Moreover, maintenance becomes an unfinished work, Asep explained:

"Fixed assets in this institutions must be well managed because the value is dominating. So far, the asset management conducted the procurement without considering any regulations. There was no recording for the procurement. In addition, the assets maintenance was not optimal"

The control activity regarding Kelabu College's fixed assets becomes a concern. The concern focuses on the materiality value of significant fixed assets in the financial statements position. So, it needs to be managed and planned well. The assets management needs to plan the procurement and improvement of fixed assets in the current year. After the planning is performed, then budget for the activity needs to be set. Budgeting is the basis for the asset to realize. After the realization process, it is important to note and maintained the fixed assets at Kelabu College. Determination of performance indicators, segregation of functions, accurate and timely recording are the final elements in control activities. Kelabu College has identified the performance indicators in each section. However, the realization and implementation have not run optimally. There are several section whose tasks are still overlapping. SPI as an unit that serves in conducting control has not provided maximum contribution. In addition to the financial aspects, SPI of Kelabu College needs to control over the HR both in the segregation of functions, performance indicators, and timely recording.

The fourth instrument of COSO including information and communication are important elements of the company's internal control. Information on control environment, risk assessment, control procedures, and monitoring is needed by the management, for operating guidelines, and guarantee for compliance with legal reporting and applicable regulations to the institutions. This fourth aspect of COSO relates with the last aspect, which is monitoring. Monitoring can be performed optimally if the information is well communicated. Kelabu College has planned and established a number of important information regarding financial management. Disbursement SOPs, budgeting SOPs, payroll regulations, and input cost unit regulations have been regulated through the head of financial sector. As stated by Atus, the head of financial sector:

"Financial SOPs are already in place and complete ... from budgeting to disbursement, to salary regulations ..."

These rules have been well communicated by the Kelabu College academicians, so that the perceptions of budget managers and users are in tune. The communication 
aspect which is emphasized by the head of SPI is related to communication on the findings of control:

\section{"LPI (SPI) communicates the control findings to the rector"}

Ideally, SPI conducts a regular (quarterly) financial control. The control aims to facilitate the duties of working unit and ensure that financial activities are in accordance with the established standards. SPI is responsible for providing explanations to the rector regarding the control findings. The concept of communication from the rector to employees regarding the control of financial statements by SPI of Kelabu College is by observing whether the financial statements prepared by the university are in accordance with the plan or not. SPI of Kelabu College provides information or reports to the rector on findings about the results of the work program performed by the university. However, if discrepancies are found, the SPI of Kelabu College needs to provide a list of fndings and recommendations for improvement.

The final aspect of COSO theory is monitoring activities. Regular monitoring of internal control system will improve the quality of control. Continuous monitoring may find deficiencies in every activity of higher education entities. Monitoring on Kelabu College has not been optimally realized. The monitoring of suitability of the financial statements preparation cannot be performed because the financial statements have not been prepared. Kelabu College only records cash flows and documents working unit accountability reports. In addition, the budget process in Kelabu College has not been performed properly. Kelabu College did not plan an annual budget, so the use of funds is not measurable and difficult to monitor. In line with what was conveyed by members of SPI at Kelabu College, Asep stated:

"The budget was not prepared but it anfrah (cash in hand for operational expenditure) only. Then, there were no financial statements. The records were only the use of funds by the faculty so monitoring could not be performed"

Similar statement is also made by Mr Asep as the Head of SPI at Kelabu College who explained that the procedure manual is not in accordance with the implementation. Especially the implementation of the preparation of financial statements and the understanding of the college budget instrument. Asep stated:

"Financial statements sometimes don't match ... not all of them understand accounting and reporting format"

The statement of the two officials above explains that the monitoring of financial activities has not been optimally implemented. Constraints such as inappropriate SOPs, understanding of accounting and financial statement format, and the absence of financial statements are the obstacles for Kelabu College to conduct regular monitoring. Kelabu College needs to attempt to develop standardized SOPs and in accordance with the entity's financial governance atmosphere. Then, they should prepare the annual budget plan that is divided into several stages of planning, determination, realization, administration, and monitoring.

\section{CONCLUSION AND SUGGESTIONS}

In short, this research explains the role of SPI in financial control that has not been optimally implemented. The elements of internal control such as aspects of monitoring activities and risk assessment have not been implemented properly. While aspects of information and communication, control activities, and control environment have been performed well. The monitoring activities has not been performed yet due to the incompatibility of SOPs and the implementation and understanding of the HR at Kelabu College regarding the financial management of the entity. The risk assessment aspect has not been realized properly. SPI has designed the potential risks but it needs to be further identified and set forth in the form of a risk assessment document. This instrument facilitates internal auditors to control risk, especially in finance. 
Control environment has been performed well, especially in the aspects of appropriate authority and responsibilities delegation, formulation and implementation of HR development policies, realization of the effective roles of SPI, and good working relations. For aspects of information and communication, Kelabu College has prepared and established a number of important information regarding financial management. Disbursement SOPs, budgeting SOPs, payroll regulations and cost unit regulations have been regulated through the head of financial sector. There are several elements of control activities, which are developing human resources, controlling of information system management, controlling of physical assets, establishing performance indicators, segregartion of functions, and accurate and timely recording. The elements of control activity have not been optimally implemented by Kelabu College.

Kelabu College is expected to improve 2 elements of COSO that have not been implemented properly including monitoring activities and risk assessment. The existing SOPs can be implemented and realized according to the timeline agreed with the working unit. In addition, the results of risk identification that have been carried out immediately are outlined in the form of documents so that they can be used as a reference by the internal auditors in conducting internal control activities. While in terms of control environment, information and communication, control activities that have been performed properly can be maintained and improved.

This research only examined one research object/site. Future research are expected to develop this research using positivism method. One alternative that can be investigated is to study the effectiveness of financial control on the reliability of financial information of private higher education.

\section{REFERENCES}

Aisyah, S., \& Asmawanti, D. (2017). Peran Satuan Pengawasan Intern dan Penerapan Pengendalian Internal terhadap Pencapaian Good University Governance pada Perguruan Tinggi di Kota Bengkulu. E-Jurnal Akuntansi Universitas Bengkulu.

Asy'ari, M. A., Prasetyono, \& Haryadi, B. (2013). Peran dan Fungsi Satuan Pengawasan Intern dalam Pencegahan Fraud pada Perguruan Tinggi X. Journal of Auditing, Finance and Forensic Accounting, 1(2), 99-112.

COSO. (2013). Internal Control Integrated Framework. Retrieved February 12, 2018, from https://www.coso.org/Pages/default.aspx

Depdiknas. Peraturan Menteri Pendidikan Nasional Republik Indonesia Nomor 16 Tahun 2009 tentang Satuan Pengawasan Internal Di Lingkungan Departemen Pendidikan Nasional (2009). Indonesia.

Detik. (2014). Kasus Korupsi IT Perpustakaan, Eks Wakil Rektor UI Dituntut 5 Tahun Penjara.

Halim, H. (2015). Legal Audit \& Legal Opinion. Jakarta: Prenadamedia Group.

Hasana, K. (2011). Ciri-Ciri Organisasi Nirlaba, Organisasi Nirlaba.

Kemendikbud. Undang-Undang No 12 Tahun 2012 tentang Pendidikan Tinggi (2012). Indonesia.

Kumaat, V. (2011). Internal Audit. Jakarta: Erlangga.

Moleong, L. (2007). Metodologi Penelitian Kualitatif. Bandung: PT. Remaja Roskdakarya.

Pontoh, C. R. S. (2013). Penerapan Laporan Keuangan Organisasi Nirlaba Berdasarkan PSAK No. 45 pada Gereja BZL. Jurnal Emba, 1(3), 129-139.

Puspitarini, N. D. (2012). Peran Satuan Pengawasan Intern dalam Pencapaian Good University Governance pada Perguruan Tinggi Berstatus PK-BLU. Accounting Analysis Journal, $1(2), \quad 1-8$. https://doi.org/https://doi.org/10.15294/aaj.v1i2.706

Trials, R. H. (2017). Peran Satuan Pengawas Internal (SPI) Dalam Pengelolaan Keuangan Universitas Halu Oleo. Universitas Haluoleo Kendari.

Ulum, I. (2012). Auditor Sektor Publik. Jakarta: PT. Bumi Aksara. 